\title{
Expression of the Inhibitory Smad7 in Early Mouse Development and Upregulation During Embryonic Vasculogenesis
}

\author{
AN ZWIJSEN, ${ }^{1,2}$ MARGA A. VAN ROOIJEN, ${ }^{3}$ MARIE-JOSÉ GOUMANS, ${ }^{3,4}$ NATHALIE DEWULF, ${ }^{1,2}$ \\ ERIKA A. BOSMAN, ${ }^{1,2}$ PETER TEN DIJKE, ${ }^{4}$ CHRISTINE L. MUMMERY, ${ }^{3 *}$ AND DANNY HUYLEBROECK ${ }^{1,2}$ \\ ${ }^{1}$ Department of Cell Growth, Differentiation, and Development (VIB07), Flanders Interuniversity Institute for Biotechnology, \\ University of Leuven, Leuven, Belgium \\ ${ }^{2}$ Laboratory of Molecular Biology (Celgen), University of Leuven, Leuven, Belgium \\ ${ }^{3}$ Hubrecht Laboratory, Netherlands Institute for Developmental Biology, Utrecht, The Netherlands \\ ${ }^{4}$ Netherlands Cancer Institute, Amsterdam, The Netherlands
}

\begin{abstract}
SMAD proteins are downstream targets of serine/threonine kinase receptors of the transforming growth factor $\beta$ (TGF $\beta$ ) superfamily. Ligands activating these receptors regulate cell growth, differentiation and development in many tissues of various organisms. In mammals eight different Smad genes are known, each with different roles in mediating signalling between plasma membrane and nucleus. Smad6 and Smad7 are inhibitors of TGF $\beta$ family signalling. They are both expressed in human adult vascular endothelial cells, particularly after these cells have been subjected to shear stress (Topper et al. [1997] Proc Natl Acad Sci USA 94: 9314-9319). Here we show by reverse transcriptase polymerase chain reaction and in situ hybridization that Smad7 mRNA is highly expressed in the developing vascular system of the mouse embryo but is also detectable much earlier in preimplantation embryos and during gastrulation. We also demonstrate by transient transgenesis that overexpression of $\mathrm{Smad} 7$ in mouse zygotes inhibits development beyond the 2-cell stage. This confirms earlier conclusions of similar, but complementary, experiments using a dominant negative type II TGF $\beta$ receptor demonstrating that TGF $\beta$ signalling is required for normal preimplantation development. () 2000 Wiley-Liss, Inc.
\end{abstract}

Key words: BMP, endothelium; in situ hybridisation; mouse development; mRNA; RT-PCR; Smad7; TGFß; vasculogenesis

\section{INTRODUCTION}

The signal transduction pathway of the TGF $\beta$ superfamily is highly conserved from invertebrates, such as Caenorhabditis elegans and Drosophila melanogaster, to vertebrates. Over 40 ligands that may activate this pathway have now been identified, with the TGF $\beta$, activins/inhibins and bone morphogenetic proteins (BMPs) forming three major subfamilies. A genetic screen for maternal enhancers of weak alleles of decapentaplegic (dpp), a BMP homologue in Drosophila, identified Mothers against $d p p(M a d)$ as part of the $D p p$ signalling pathway while subsequent analysis of C. elegans mutants identified sma-2, 3, and 4 as genes giving phenotypes similar to mutations in $d a f 4$, a receptor for a BMP-like ligand in the nematode (reviewed in Kawabata et al., 1998). The similarities in function and in protein structure, together with sequence homology, were the first strong suggestions that Mad and sma form part of a conserved, intracellular signalling pathway for the TGF $\beta$ superfamily.

Eight Smad genes were subsequently identified in mammals and grouped into three classes based on their structure and function (reviewed in Massagué et al., 1998; Heldin et al., 1997). Pathway-restricted or receptor-regulated SMADs (R-Smads) are directly phosphorylated by type I receptors following transient interaction. Smad2 and 3 are substrates for activated TGF $\beta$ and activin type I receptors, whereas Smad1, 5, and 8 interact with BMP type I receptors. Phosphorylated R-Smads oligomerize with Smad4, which belongs to the class of common-mediator or Co-Smads. These Smad complexes accumulate in the nucleus where they participate in the regulation of transcription of a specific set of responsive genes. Smads of the third class antagonize TGFß/activin and/or BMP signalling by preventing the activation of the R-Smads or their subsequent oligomerization with the Co-Smads (Hayashi et al., 1997; Imamura et al., 1997; Nakao et al., 1997; Hata et al., 1998). Two of these inhibitory Smads (ISmads or anti-Smads), Smad 6 and 7, have been identified to date. Both inhibit BMP signalling but Smad7 is more potent in inhibiting TGF $\beta$ /activin signals than

Grant sponsor: FWO-V; Grant number: G.0296.98; Grant sponsor: Netherlands Heart Foundation; Grant number: 99-046; Grant sponsor: EU-TMR; Grant number: ERB-4061-PL-97-1010.

A. Zwijsen and M.A. van Rooijen contributed equally to this work.

*Correspondence to: Christine L. Mummery, Hubrecht Laboratory, Netherlands Institute for Developmental Biology, Uppsalalaan 8, 3584 CT Utrecht, The Netherlands. E-mail: christin@niob.knaw.nl 
A

C

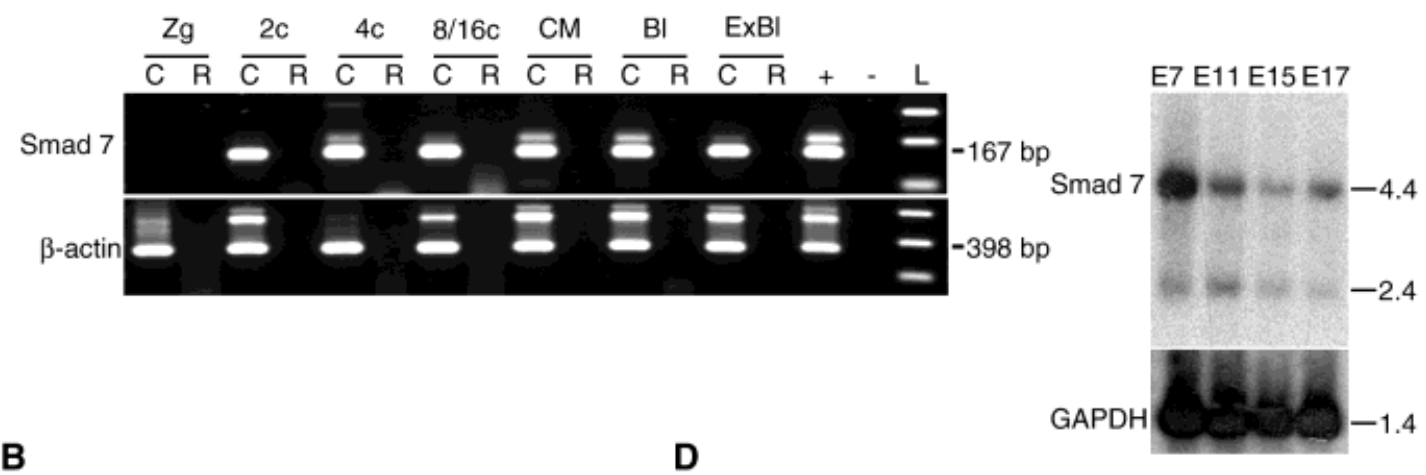

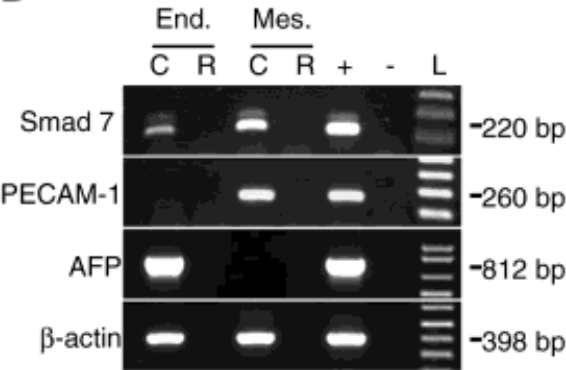

Fig. 1. RT-PCR amplification of Smad7 mRNA in pre- and postimplantation $(A, B, D)$ mouse embryos. One $(B, D)$ or two $(A)$ rounds of $P C R$ were performed on cDNA from embryonic stages between one-cell zygote and expanded blastocyst (A), pregastrulation and early headfold stages (D) and separated tissue layers of the yolk sac (B) to amplify Smad7 mRNA (top panels). RT-PCR amplification of $\beta$-actin transcripts (bottom panels) served as control for RNA extraction and cDNA synthesis. cDNA from embryonic stem (ES) cells was used as positive control $(+)$ for amplification. Water served as a negative control (-). AFP and $P E C A M-1$ expression were used to verify separation of the yolk sac layers (B). The upper transcripts in (A) represent first round carry-over products. (C) Expression of Smad7 in postimplantation mouse embryos. A Northern blot with polyA ${ }^{+}$RNA was hybridized to the Smad7 probe. Rehybridization with GAPDH confirmed equal mRNA loading in each lane. Abbreviations: 2c, 4c, 8/16c: 2-, 4- and 8 to 16-cell stage respectively; BI, blastocyst; C, cDNA: CM, compacted morula, e, embryonic region; ex, extraembryonic region; End, yolk sac endoderm; ExBI, expanded blastocyst; L, DNA ladder; Mes, yolk sac mesoderm; R, RNA; Zg, zygote.
Smad6 (Imamura et al., 1997, Nakao et al., 1997; Ishisaki et al., 1998, 1999; Hata et al., 1998; Nakayama et al., 1998a; Casellas and Hemati-Brivanlou, 1998). mRNAs for both Smad6 and Smad7 are also induced by BMPs and TGF $\beta$ although with different kinetics; Smad6 is induced three hours after ligand stimulation and is maintained for more than 48 hours, whereas Smad7 induction is more rapid but only transient (Afrakhte et al., 1998; Takase et al., 1998). Together the findings suggest that I-Smad genes are induced by R-Smads and may regulate their activity by a negative feedback loop.

Smad7 was identified among genes upregulated in a differential screen of vascular endothelial cells subjected to shear stress; in adults it manifested an endothelial selective expression pattern (Topper et al., 1997). Since TGF $\beta$ signalling in endothelial cells also plays a crucial role in the pathology of several vascular diseases (McAllister et al., 1994; Johnson et al., 1996), and is essential for normal vasculogenesis of the yolk sac in mouse development (Dickson et al., 1995; Goumans et al., 1999), we examined Smad7 mRNA expression in mouse development. The results described here show that Smad7 is indeed highly ex- pressed in the endothelial cells of the developing vascular system, as in adults, but is also detectable much earlier in preimplantation embryos and in gastrulation. In addition by overexpressing $S m a d 7$ in zygotes, we confirm a functional requirement for TGF $\beta$ signalling in preimplantation development, first observed in embryos expressing dominant negative TGF $\beta$ receptors (Roelen et al., 1998), later demonstrated in certain strains of mice lacking TGF $\beta 1$ (Kallapur et al., 1999).

\section{RESULTS}

\section{Smad7 Expression in Early Development}

Expression of Smad7 mRNA during early mouse development was determined by RT-PCR. Smad7 was not present as maternal transcripts in the zygote but became detectable in embryos at the 2-cell stage, when embryonic transcription begins; expression was maintained throughout preimplantation development (Fig. 1A). After implantation, Smad7 mRNA was not detectable by RT-PCR in prestreak embryos at E6.0 (Fig. 1D), but transcripts were observed in both embryonic and extraembryonic regions from E6.5 onwards (Fig. 1D). Since type I receptors for TGF $\beta$ (ALK5), activin (ALK4) and BMPs $(A L K 2, A L K 3$, and $A L K 6)$ are expressed 


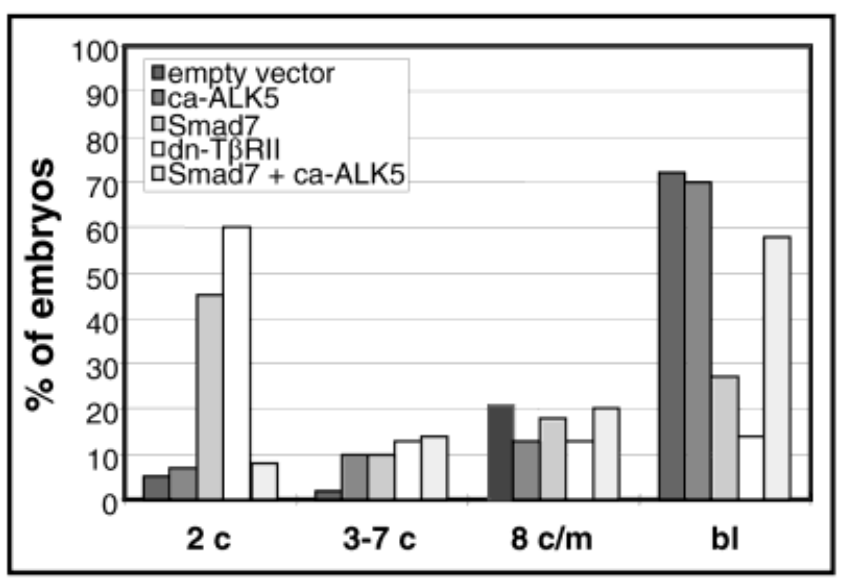

Fig. 2. Overexpression of Smad7 causes embryos to become developmentally arrested at the two-cell stage. Fertilized oocytes were injected with $10 \mathrm{fg}$ of the constructs indicated. After 3 days of culture, the percentages of embryos at the 2-cell stage, 3-7 cell stages, 8 cell-morula and blastocyst stages were scored. $\mathrm{N}=25$ successfully injected embryos for each construct or combination of constructs. The data shown are from one of two identical experiments giving similar results. Positive ( $d n T \beta R I I)$ and negative (caALK-5) controls reproduce previous findings (Roelen et al., 1998).

during these stages (Roelen et al., 1997a, 1997b; Gu et al., 1998), they are candidates for negative regulation by Smad7.

\section{Smad7 Overexpression Inhibits First Cleavage}

We have demonstrated previously that if TGF $\beta$ signalling in the zygote is inhibited by overexpression of $d n-T \beta R I I$, lacking the intracellular kinase domain, the embryos do not develop beyond the 2-cell stage (Roelen et al., 1998). This effect was rescued by co-expression of a constitutively active TGF $\beta$ type I receptor (ca-ALK5). Since Smad7 can also inhibit TGF $\beta$ signalling, we injected a DNA construct encoding Smad7, driven by the $P G K-1$ promoter, into the male pronuclei of fertilized eggs. The embryos were subsequently cultured for three days and scored for their developmental stage. After 24 hours, the embryos that had not developed to the 2-cell stage were discarded (these were primarily unfertilized oocytes); there was no difference in the percentage of embryos remaining as one cell between the experimental groups (data not shown). After three days in culture, more than $70 \%$ of the embryos injected with empty vector had developed to blastocysts (Fig. 2); this compares with $\sim 80 \%$ of non-injected controls (data not shown). By contrast less than $30 \%$ of the embryos injected with the Smad7 cDNA had reached this stage and $45 \%$ did not develop beyond the 2-cell stage. There was no evidence of apoptosis in the embryos remaining at the 2-cell stage (data not shown). These results compare with $60 \%$ of embryos injected with a $d n-T \beta R I I$ construct remaining at the 2-cell stage (Fig. 2). Coinjection of $c a-A L K 5$, that mimics ligand-activation (see Roelen et al., 1998) largely rescued the Smad7-induced inhibition of cleavage, but itself had no effect on the efficiency of development (Fig. 2).

\section{Smad7 Expression in Postimplantation Development to Mid-Gestation}

We also used in situ hybridisation to map the distribution of Smad7 in sections of embryos during postimplantation development (E6.5-E12.5). The specificity of the probe was verified by Northern blot analysis of polyA $^{+}$RNA from mouse embryos. Smad7 transcripts of 4.4 and $2.4 \mathrm{~kb}$ are present throughout mouse development (Fig. 1C). In situ hybridisation confirmed that Smad7 is weakly expressed in the epiblast at E6.5 (Fig. 3A). At E7.5, high levels of transcripts were observed in the extraembryonic mesodermal cells of the allantois (Fig. 3C). The yolk sac (extraembryonic mesoderm and visceral endoderm) was weakly positive for $S m a d 7$ (Fig. 3C), but we confirmed by RT-PCR that the signal was specific and above background (Fig. 1B). A Smad7 transcript was detected in both the endoderm and mesoderm components of the yolk sac, while RT-PCR to detect $\alpha$-fetoprotein $(A F P)$ and platelet endothelial cell adhesion molecule 1 (PECAM-1), which are markers for endoderm and mesoderm respectively, confirmed that the two tissue samples had been cleanly separated (Fig. 1B). The inner layer of the deciduum and the trophoblast giant cells were also positive, both at E7.5 and at E8.0 (Fig. 2B-G). In the embryo proper at E7.5, the $S \operatorname{mad} 7 \mathrm{mRNA}$ level was low in all three embryonic germ layers (Fig. 3B), and similar to that observed in the epiblast at E6.5 (Fig. 3A); again, however, RT-PCR data confirmed that the signal did not represent nonspecific background (Fig.1D).

Distinct, regionalized expression of $\mathrm{Smad} 7$ in the embryo proper was first observed from E8.0 onwards. Lateral plate mesoderm (splanchno- and somatopleure) (Fig. 3G) and cardiac mesoderm (Fig. 3E) expressed higher levels of Smad7 transcript than the endoderm, the neuroectoderm, and the paraxial and cephalic mesoderm (Fig. 3D-G).

At E12.5, when primordia of most organs have been established, most prominent expression was in aorta and arteries, the outflow tract and regions involved in heart septation (Fig. 4C-E). Expression was somewhat higher in arteries than in veins (e.g., thoracic artery positive, with the adjacent thoracic vein negative). The mouse embryo then adopted the expression pattern described for adult human endothelium (Topper et al., 1997). Multiple members of the TGF $\beta$ family have been implicated in cardiogenesis and differentiation of endothelium. Partial co-localisation of their type I receptors $A L K 1, A L K 3, A L K 5$, and ALK6, and Smad7 occurs at those sites (Roelen et al., 1994, 1997b; Dewulf et al., 1996).

Smad7 was also expressed in precartilage condensations, the urogenital system, distinct neuroectodermal tissues and derivatives of the lateral plate mesoderm (summarized in Table 1; Fig. 4). 

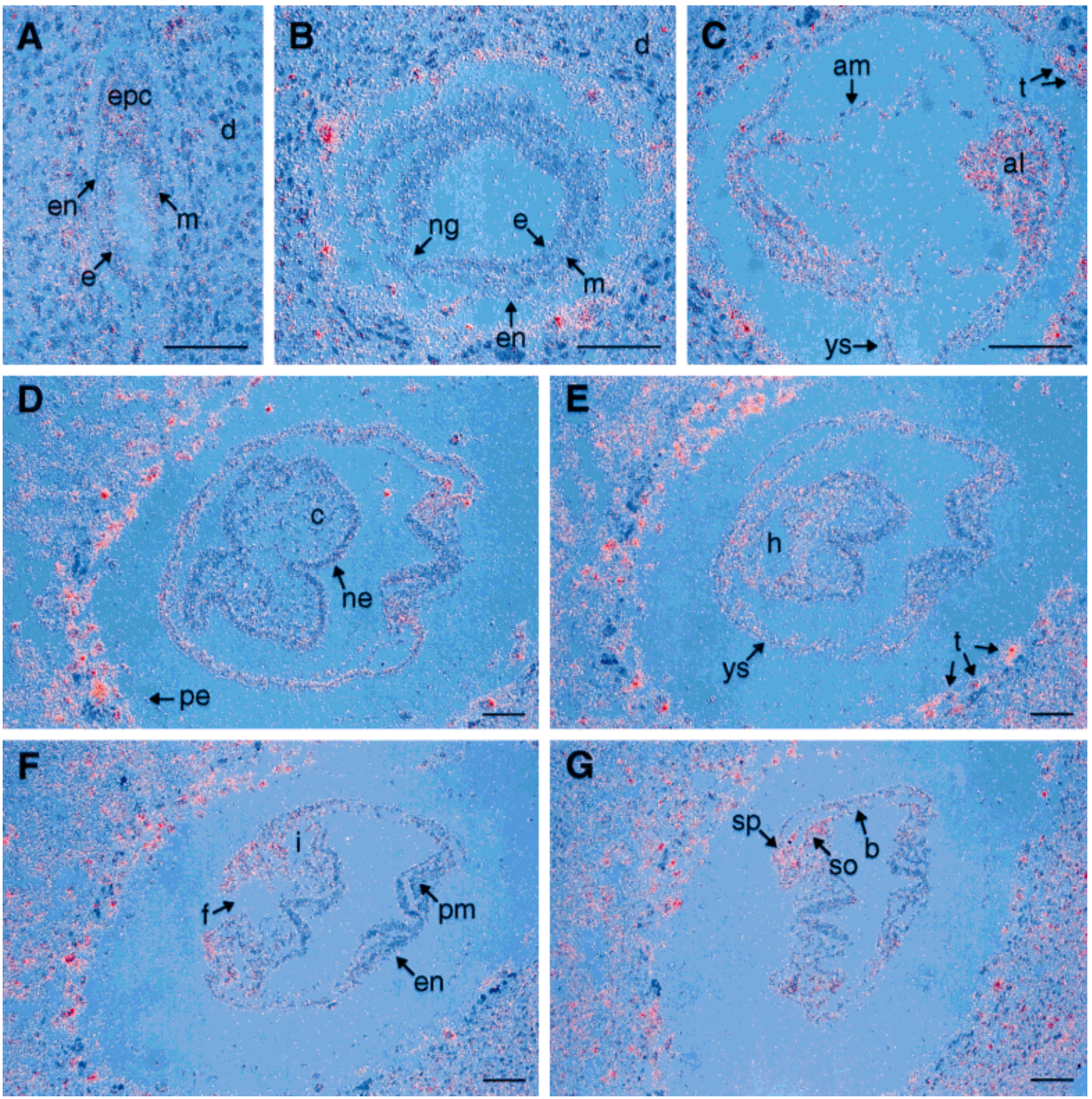

Fig. 3. Expression of Smad7 in early postimplantation embryos. Sections of embryos in decidua at E 6.5 (A; sagittal), E7.5 (B, C; transverse) and E8.0 (D-G; transverse). Abbreviations: al, allantois; am, amnion; b, body wall; c, cephalic mesoderm; d, deciduum; e, ectoderm; en, endoderm; epc, ectoplacental cone; f, entrance to foregut diverticulum; $h$,

heart primordium; i, intraembryonic coelomic cavity; m, mesoderm; ne, neuroectoderm; ng, neural groove; pe, parietal endoderm; pm, paraxial mesoderm; so, somatopleura; sp, splanchnopleura; t, trophoblast giant cells; ys, yolk sac. Scale bars $=100 \mu \mathrm{m}$.

\section{DISCUSSION}

In the present study we have shown that $\operatorname{Smad} 7$ is widely expressed throughout mouse development, not only at sites of embryonic vasculogenesis, but also during preimplantation development and gastrulation. This is largely in agreement with studies in Xenopus laevis (Casellas and Hemmati-Brivanlou, 1998; Na-

kayama et al., 1998b). Restricted expression in the embryo proper was first observed at E8.0 where it was most evident in cells and tissues of mesodermal origin. By E12.5 it had adopted an expression pattern essentially as described for that of adult human endothelium being particularly prominent in the outflow tract of the heart, tissues involved in its septation, in the aorta and 

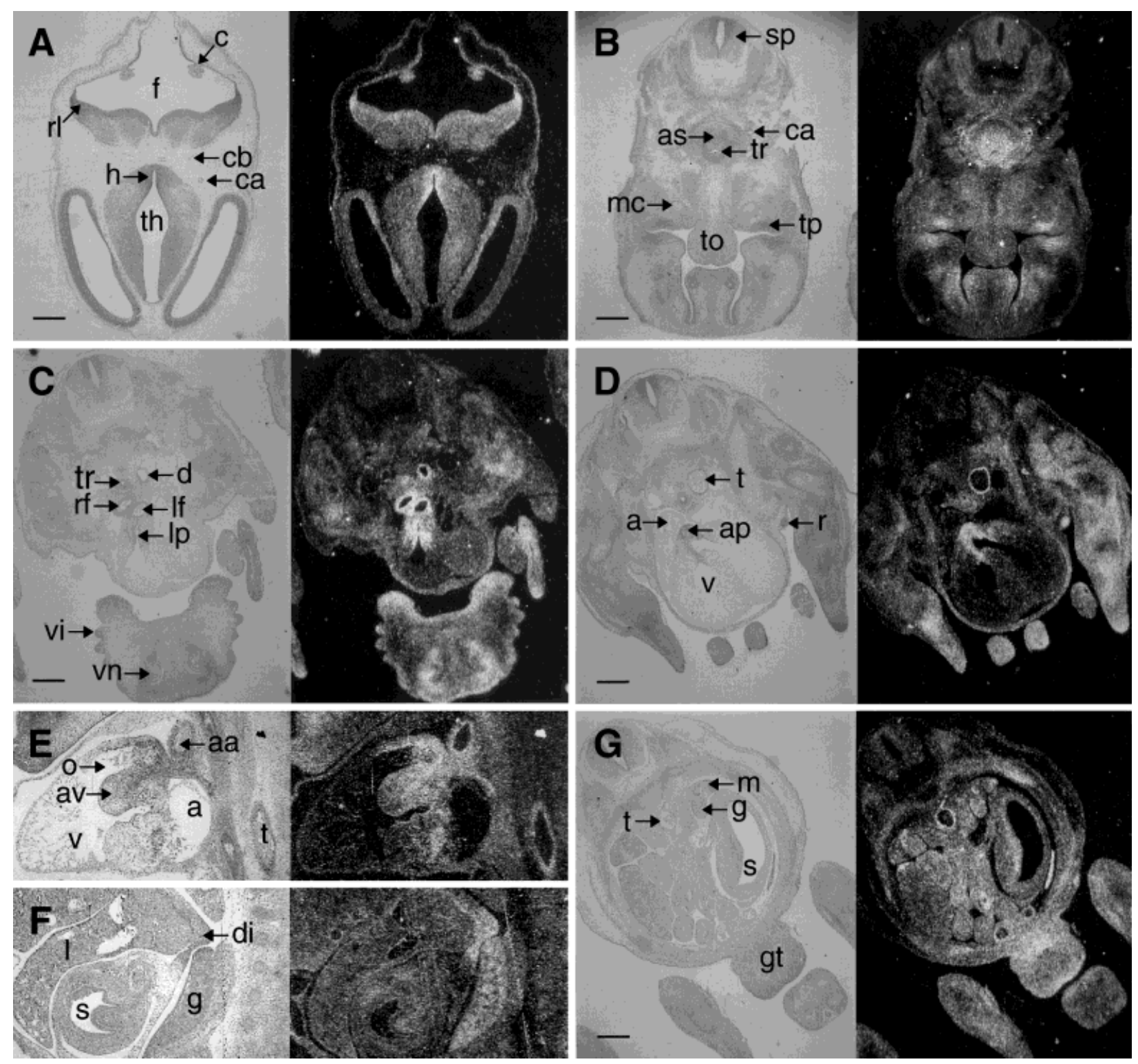

Fig. 4. Expression of Smad7 in E12.5 embryos. Transverse sections through head (A, B), heart (D, E) and abdomen $(\mathbf{G})$. Sagittal sections through heart $(\mathbf{C})$ and abdomen $(\mathbf{F})$. Abbreviations: a, lumen of atrium; aa, arch of aorta; ap, aortico-pulmonar spiral septum; as, arytenoid swelling; av, atrioventricular cushion tissue; c, choroid plexus; ca, carotid artery; cb, cerebral artery; d, dorsal aorta; di, diaphragm; $f$, fourth ventricle; g, gonad; gt, genital tubercle; h, hypothalamus; I, liver; If, left fourth

in other major arteries. Smad7 was originally identified as a gene induced in endothelial cells subjected to shear stress (Topper et al., 1997). The higher expression in arteries versus veins in the embryo may therefore reflect differences in shear stress to which they are exposed as the circulation develops.

Smad7 has also been documented as being upregulated in several cell types exposed to ligands of the TGF $\beta$ superfamily, thus forming a negative feedback loop in the response to ligand. We have demonstrated

arch artery; Ip, leaflets of pulmonary valve; lu, lung; m, mesonephros; mc Meckel's cartilage; o, outflow tract; $p$, precartilage primordium; $r$, rib shaft; rf, right fourth arch artery; rl, rhombic lip; s, stomach; sp, spinal cord; t, thoracic aorta; th, third ventricle; tr, trachea; to, tongue; tp, tooth primordium; v, lumen of ventricle; vi, vibrissae; vn, vomeronasal organ. Scale bars $=250 \mu \mathrm{m}$.

in the present study that $S m a d 7$ expression is upregulated at the onset of embryonic transcription; no transcripts were detectable by RT-PCR in zygotes but expression was clearly evident at the 2 -cell stage. TGF $\beta$ receptor expression is the exact converse: mRNAs for both $T \beta R I I$ and $T \beta R I(A L K 5)$ are detectable in zygotes and their levels decrease so that neither is detectable by the 4-cell stage (Roelen et al., 1998). Since receptor expression precedes that of $S m a d 7$, it is conceivable that TGF $\beta$ signalling is responsible for its initial up- 
TABLE 1. Smad7 Expression in E12.5 Mouse Embryos as Determined by In Situ Hybridisation

\begin{tabular}{|c|c|c|c|}
\hline Tissue & mRNA & Tissue & mRNA \\
\hline Nervous system & & Stomach/intestines & \\
\hline Brain & + & Mucosal-epithelium & - \\
\hline Spinal cord & $+1-$ & Submucosal layer & + \\
\hline DR ganglia & - & Muscle layer & - \\
\hline Meninges & $+/-$ & Lung & \\
\hline Cerebral peduncle & - & Mesenchyme & - \\
\hline Choroid plexus & + & Epithelium & - \\
\hline Trigeminal ganglion & + & Liver & - \\
\hline Left vagus nerve & - & Pancreas & - \\
\hline Optic nerve & - & Pituitary & + \\
\hline Optic chiasma & - & Thymic primordium & - \\
\hline Vestibulocochlear nerve & + & Adrenal primordium & $+1-$ \\
\hline Nephrogenic system & & Vomeronasal organ & + \\
\hline Mesonephros & $+1-$ & Olfactory lobe & $+^{\mathrm{m}}$ \\
\hline Paramesonephric duct & + & Cochlea & + \\
\hline Metanephros & $+1-$ & Tooth primordium & + \\
\hline Gonad & + & Infindibulum & + \\
\hline Cardiovascular system & & Tongue & - \\
\hline Heart & & Vibrissae & + \\
\hline Atrium & - & Oesophagus & - \\
\hline Ventricle & - & Trachea & + \\
\hline Pericard & - & Pharynx & - \\
\hline Leaflets of pulmonary valve & ++ & Eye & \\
\hline Atrio-ventricular cushion & ++ & Lens & - \\
\hline Blood vessels & & Cornea & - \\
\hline Dorsal aorta & ++ & Retina & - \\
\hline Thoracic aorta & ++ & Notochord & - \\
\hline Carotid arteries & + & Erythrocyte & - \\
\hline Cerebral arteries & + & Genital tubercle & + \\
\hline Vertebral arteries & + & Meckel's cartilage & - \\
\hline Spinal cord artery & - & Intevertebral discs & - \\
\hline Umbilical cord & + & Dermomyotome & $+1-$ \\
\hline Segmental arteries & + & Pinna primordium & - \\
\hline Hyoid vessels & - & Body wall & - \\
\hline Jugular veins & - & Diaphragm & + \\
\hline Inferior vena cava & + & Precartilage primordium & + \\
\hline
\end{tabular}

${ }^{m}$ mesenchyme only, -: no expression, +/-: either background, or very weak expression, + : moderate expression, ++ : high expression.

regulation. In later development, trophoblast giant cells, yolk sac mesoderm, the heart, choroid plexus, submucosal layer of the stomach, and the kidneys express both $S m a d 7$ and TBRII (Roelen et al., 1994; Goumans et al., 1999), so again, Smad7 could be upregulated by TGF $\beta$ signalling. The effects may be mediated by Smad 4 in combination with either Smad2 or Smad3 since both are detectable in the embryo proper by E7.5 (Zwijsen et al., 1999). In the light of the restricted expression pattern of $T \beta R I I$, particularly at early postimplantation stages, however (Roelen et al., 1994), other ligands are also likely to be involved in regulating Smad7. For example, activin (or a ligand binding to its receptors) could be responsible for the observed upregulation of Smad7 between E7.5 and $\mathrm{E} 8.5$, in precartilage condensations, the brain and in the urogenital system (Feijen et al., 1994; Verscheuren et al., 1995; see Mummery and van den Eijnden-van Raaij, 1999 for a review of receptor/ligand expression patterns).

In a previous study, we have shown by transient expression of dnT $\beta$ RII in zygotes that development beyond the 2-cell stage requires an intact TGF $\beta$ signalling pathway although we do not know the molecular basis for this effect. Here, we have demonstrated that overexpression of $\mathrm{Smad7}$, which would also inhibit TGF $\beta$ signalling but in a manner different from that following ectopic expression of a dominant negative receptor, results in a similar failure to proceed beyond the 2-cell stage of development. Taken together, the results demonstrate that fine-tuning of TGF $\beta$ signalling via proteins that may include Smad7 could be crucial to very early normal development. Gene ablation studies and conditional or tissue specific overexpression should provide the clues on whether Smad7 has a function at other sites of expression during later stages of development.

\section{EXPERIMENTAL PROCEDURES Collection, Microinjection, and Culture of Embryos}

For reverse transcription-polymerase chain reaction (RT-PCR) and in situ hybridisation analysis, mouse embryos from $\mathrm{F} 1$ crosses of C57B16 $\times$ CBA strains were 
collected and processed as described before (Dewulf et al., 1996, Roelen et al., 1997b). For zygote injection, Smad7 cDNA was cloned into an expression vector containing the mouse phosphoglycerate kinase-1 (PGK) promoter sequence (Adra et al., 1987). This vector was linearized and the DNA dissolved in injection buffer at a final concentration of $2-8 \mathrm{ng} / \mu \mathrm{l}$, as described previously (Roelen et al., 1998). Approximately $5 \mathrm{pl}$ of plasmid DNA was injected into the male pronucleus of one-cell zygotes; embryos undergoing successful injection of either Smad7 plasmid DNA or empty vector, monitored by nuclear swelling, were transferred to M16 medium for culture. Three days later, when uninjected control embryos had developed to blastocysts, all embryos were scored for developmental stage (Roelen et al., 1998). A construct encoding dominant negative type II TGF $\beta$ receptor ( $d n-T \beta R I I)$ or coding for a constitutively phosphorylated type 1 TGF $\beta$ receptor (ca$A L K 5)$ were injected, either to act as negative controls or to rescue the phenotype, respectively (Roelen et al., 1998).

\section{RNA Isolation, cDNA Synthesis, and PCR}

RNA isolation, subsequent cDNA synthesis and PCR were as described (Roelen et al., 1997a). 5'-CCTCCTCCTTACTCCAGATA-3', 5'-TCTTGGACACAGTAGAGCCT- ${ }^{\prime}$ ' and 5'-ACGCACCAGTGTGACCGATC-3' were used as forward, reverse, and internal reverse primer (annealing temperature: $58^{\circ} \mathrm{C}$ ), to amplify the region corresponding to nucleotides 929-1148 and 929-1095 of the mouse Smad7 sequence (Nakao et al., 1997). Primers used for $\beta$-actin and for PECAM-1 and AFP are described in Roelen et al. (1997a) and Goumans et al. (1999), respectively. Groups of 15-20 preimplantation and 10 (microdissected) postimplantation embryos were pooled to extract RNA. PCR was carried out using 1 embryo equivalent. Experiments were carried out on 3-4 independent samples.

\section{Northern Blotting and In Situ Hybridisation}

A Smad7 specific 260 bp-long HindII-EcoRV cDNA fragment (Nakao et al., 1997), subcloned into pBS $\mathrm{SK}+$, was used as probe. A mouse embryo poly- $\mathrm{A}^{+}$ RNA blot (Clontech) was hybridized with randomprimed $S m a d 7$ probe to check for its specificity. Equal loading of mRNA was confirmed by rehybridisation of the blot with $G A P D H$. In vitro transcription with T3 or T7 RNA Polymerase yielded ${ }^{35}$ S-labelled singlestranded antisense (EcoRI) or sense (NotI) Smad7 riboprobes. The $S m a d 7$ antisense probe did not show signal above background by in situ hybridization at any developmental stage tested (data not shown).

\section{ACKNOWLEDGMENTS}

We thank M. Reinen for zygote injection, Drs. H. Kraft and T. van de Putte for the Northern blot and Dr. $\mathrm{K}$. Verschueren for critical reading of the manuscript. This study was supported by FWO-V grant G.0296.98 (to A.Z and D.H.), Netherlands Heart Foundation grant
99-046 (to P.t.D and C.L.M.) and EU-TMR grant ERB4061-PL-97-1010 (to P.t.D and D.H.). E.B was an IWT pre-doctoral fellow; D.H. was supported by VIB.

\section{REFERENCES}

Adra CN, Boer PH, McBurney MW. 1987. Cloning and expression of the mouse pgk-1 gene and the nucleotide sequence of its promoter. Gene 60:65-74.

Afrakhte M, Morén A, Jossans S, Itoh S, Sampath K, Westermark B, Heldin C-H, Heldin N-E, ten Dijke P. 1998. Induction of inhibitory Smad6 and Smad 7 mRNA by TGF- $\beta$ family members. Biochem Biophys Res Commun 249:505-511.

Casellas R, Hemmati-Brivanlou A. 1998. Xenopus Smad7 inhibits both the activin and BMP pathways and acts as a neural inducer. Dev Biol 198:1-12.

Dewulf N, Verschueren K, Lonnoy O, Morén A, Grimsby S, Vande Spiegle K, Miyazono K, Huylebroeck D, ten Dijke P. 1996. Distinct spatial and temporal expression patterns of two type I receptors for bone morphogenetic proteins during mouse embryogenesis. Endocrinology 136:2652-2663.

Dickson MC, Martin JS, Cousins FM, Kulkarni AB, Karlsson S, Akhurst RJ. 1995. Defective haematopoiesis and vasculogenesis in transforming growth factor- $\beta 1$ knockout mice. Development 121 : 1845-1854.

Feijen A, Goumans M-J, van den Eijnden-van Raaij AJM. 1994. Expression of activin subunits, activin receptors and follistatin in post-implantation mouse embryos suggests specific developmental functions of different activins. Development 120:3621-3637.

Goumans M-J, Zwijsen A, van Rooijen M, Huylebroeck D, Roelen B, Mummery CL. 1999. Transforming growth factor $\beta$ signaling in extraembryonic mesoderm is required for yolk sac vasculogenesis in mice. Development 126:3473-3483.

Gu Z, Nomura M, Simpson BB, Lei H, Feijen A, van den Eijnden-van Raaij AJM, Donahoe P, Li E. 1998. The type 1 activin receptor ActR1B is required for egg cylinder organization and gastrulation in the mouse. Genes Dev 12:844-857.

Hata A, Lagna G, Massagué J, Hemmati-Brivanlou A. 1998. Smad6 inhibits BMP/Smad1 signaling by specifically competing with the Smad4 tumor suppressor. Genes Dev 12:186-197.

Hayashi H, Abdollah S, Qiu Y, Cai J, Xu YY, Grinnell BW, Richardson MA, Topper JN, Gimbrone MA Jr, Wrana JL, Falb D. 1997. The MAD-related protein Smad7 associates with the TGF $\beta$ receptor and functions as an antagonist of TGF $\beta$ signalling. Cell 89:1165-1173.

Heldin C-H, Miyazono K, ten Dijke P. 1997. TGF- $\beta$ signalling from cell membrane to nucleus through Smad proteins. Nature 390:465471.

Imamura T, Nishihara A, Oeda E, Hanai J-i, Kawabata M, Miyazono K. 1997. Smad6 inhibits signalling by the TGF- $\beta$ superfamily. Nature 389:622-626.

Ishisaki A, Yamato K, Nakao A, Nonaka K, Ohguchi M, ten Dijke P, Nishihara T. 1998. Smad7 is an activin-inducible inhibitor of activin-induced growth arrest and apoptosis in mouse B cells. J Biol Chem 273:24293-24296.

Ishisaki A, Yamato K, Hashimoto S, Nakao A, Tamaki K, Nonaka K, ten Dijke P, Sugino H, Nishihara T. 1999. Differential inhibition of Smad6 and Smad7 on bone morphogenetic protein- and activin-mediated growth arrest in B cells. J Biol Chem 274: 13637-13642.

Johnson DW, Berg JN, Baldwin MA, Gallione CJ, Marondel I, Yoon SJ, Stenzel TT, Speer M, Pericak-Vance MA, Diamond A, Guttmacher AE, Jackson CE, Attisano L, Kucherlapati R, Porteous ME, Marchuk DA. 1996. Mutations in the activin receptor-like kinase 1 gene in hereditary haemorrhagic telangiectasia type 2. Nat Genet 13: $189-195$.

Kallapur S, Ormsby I, Doetschman T. 1999. Strain dependency of TGF $\beta 1$ function during embryogenesis. Mol Reprod Dev 52:341-349 Kawabata M, Imamura T, Miyazono K. 1998. Signal transduction by bone morphogenetic proteins. Cytokine Growth Factor Rev 9:4965. 
Massagué J. 1998. TGF- $\beta$ signal transduction. Ann Rev Biochem 67:753-791.

McAllister KA, Grogg KM, Johnson DW, Gallione CJ, Baldwin MA, Jackson CE, Helmbold EA, Markel DS, McKinnon WC, Murrell J, et al. 1994. Endoglin, a TGF- $\beta$ binding protein of endothelial cells, is the gene for hereditary haemorrhagic telangiectasia type 1 . Nat Genet 8:345-351

Mummery CL, van den Eijnden-van Raaij AJM. 1999. Developmental tumours, early differentiation and the transforming growth factor $\beta$ superfamily. Int J Dev Biol 43:693-709.

Nakao A, Afrakhte M, Moren A, Nakayama T, Christian JL, Heuchel R, Itoh S, Kawabata M, Heldin NE, Heldin C-H, ten Dijke P. 1997. Identification of Smad7, a TGF $\beta$ inducible antagonist of TGF $\beta$ signalling. Nature 389:631-635.

Nakayama T, Gardner H, Berg LK, Christian JL. 1998a. Smad6 functions as an intracellular antagonist of some TGF- $\beta$ family members during Xenopus embryogenesis. Genes Cells 3:387-394.

Nakayama T, Snyder MA, Grewal SS, Tsuneizumi K, Tabata T, Christian JL. 1998b. Xenopus Smad8 acts downstream of BMP-4 to modulate its activity during vertebrate embryonic patterning. Development 125:857-867.

Roelen BA, Lin HY, Knezevic V, Freund E, Mummery CL. 1994. Expression of TGF $\beta$ s and their receptors during implantation and organogenesis of the mouse embryo. Dev Biol 166:716-728.

Roelen BAJ, van Rooijen MA, Mummery CL. 1997a. Expression of ALK-1, a type 1 serine/threonine kinase receptor, coincides with sites of vasculogenesis and angiogenesis in early mouse development. Dev Dyn 209:418-430.

Roelen BAJ, Goumans M-J, van Rooijen MA, Mummery CL. 1997b. Differential expression of BMP receptors in early mouse development. Int J Dev Biol 41:541-549.

Roelen BAJ, Goumans M-J, Zwijsen A, Mummery CL. 1998. Identification of two distinct functions for TGF- $\beta$ in early mouse development. Differentiation 64:19-31.

Takase M, Imamura T, Sampath TK, Takeda K, Ichijo H, Miyazono K, Kawabata M. 1998. Induction of Smad6 mRNA by bone morphogenetic proteins. Biochem Biophys Res Commun 244:26-29.

Topper JN, Cai J, Qiu Y, Anderson KR, Xu YY, Deeds JD, Feeley R, Gimeno CJ, Woolf EA, Tayber O, Mays GG, Sampson BA, Schoen FJ, Gimbrone MA Jr, Falb D. 1997. Vascular MADs: two novel MAD-related genes selectively inducible by flow in human vascular endothelium. Proc Natl Acad Sci USA 94:9314-9319.

Verscheuren K, Dewulf N, Goumans M-J, Lonnoy O, Feijen A, Grimsby S, Vande Spiegle K, ten Dijke P, Morén A, Vanscheeuwijck P, Heldin C-H, Miyazono K, Mummery CL, van den Eijnden-van Raaij AJM, Huylebroeck D. 1995. Expression of type 1 and type1B receptors for activin in midgestation mouse embryos suggests distinct functions in organogenesis. Mech Dev 52:109-123.

Zwijsen A, Goumans M-J, Lawson KA, van Rooijen MA, Mummery CL. 1999. Ectopic expression of the transforming growth factor $\beta$ type II receptor disrupts mesoderm organisation during mouse gastrulation. Dev Dyn 214:141-151. 